\title{
Monuments, mobility and Medieval perceptions of designed landscapes: The Pleasance, Kenilworth
}

Article

Accepted Version

Jamieson, E. and Lane, R. (2015) Monuments, mobility and Medieval perceptions of designed landscapes: The Pleasance, Kenilworth. Medieval Archaeology, 59 (1). pp. 255-271. ISSN 0076-6097 doi:

https://doi.org/10.1080/00766097.2015.1119394 Available at https://centaur.reading.ac.uk/48502/

It is advisable to refer to the publisher's version if you intend to cite from the work. See Guidance on citing.

To link to this article DOI: http://dx.doi.org/10.1080/00766097.2015.1119394

Publisher: Taylor \& Francis

All outputs in CentAUR are protected by Intellectual Property Rights law, including copyright law. Copyright and IPR is retained by the creators or other copyright holders. Terms and conditions for use of this material are defined in the End User Agreement.

www.reading.ac.uk/centaur 
Central Archive at the University of Reading

Reading's research outputs online 
PRELIMINARY PAGE

\begin{tabular}{|l|l|}
\hline Title: & $\begin{array}{l}\text { Monuments, Mobility and Medieval Perceptions of Designed } \\
\text { Landscapes: The Pleasance, Kenilworth }\end{array}$ \\
\hline Abbreviated title: & The Pleasance, Kenilworth \\
\hline Name of author(s): & $\begin{array}{l}\text { Elaine Jamieson } \\
\text { Investigator } \\
\text { Assessment Team (West) } \\
\text { English Heritage }\end{array}$ \\
& $\begin{array}{l}\text { Rebecca Lane } \\
\text { Investigator } \\
\text { Assessment Team (West) } \\
\text { English Heritage }\end{array}$ \\
\hline Word count: & $\begin{array}{l}\text { 6,575 } \\
\text { Correspondence: }\end{array}$ \\
\hline $\begin{array}{l}\text { Rebecca Lane } \\
\text { Swindon } \\
\text { Assessment Team (West) } \\
\text { English Heritage } \\
\text { The Engine House }\end{array}$ \\
\hline
\end{tabular}




\section{Monuments, Mobility and Medieval Perceptions of Designed Landscapes: The}

\section{Pleasance, Kenilworth}

By Elaine Jamieson ${ }^{\mathrm{i}}$ and Rebecca Lane $\mathrm{e}^{\mathrm{ii}}$

The Pleasance was a' virandarium' or pleasure garden, constructed by Henry V in the grounds of his castle at Kenilworth. Despite its high academic profile and the survival of well-preserved earthwork remains, the Pleasance has never previously been subjected to a programme of detailed archaeological survey and investigation. This article discusses the results of a new analytical earthwork survey undertaken by staff from English Heritage in 2012. It considers the contribution that these new findings make to the wider debate on medieval designed landscapes, with a particular focus on mobility and its role in unlocking the meaning and symbolism embedded in elite landscapes.

Kenilworth Castle, located in the Arden region of Warwickshire, is one of the largest castles in England and was in royal hands for much of its history. Surrounding the castle in the medieval period were extensive pleasure grounds, a key component of which was a large detached garden known as the Pleasance. As a well-documented and rare example of a royal pleasure garden, and one which formed part of a wider medieval designed landscape, the Pleasance represents a relict garden of international significance. Constructed by Henry V in the early 15th century, the garden was located approximately a kilometre to the west of the castle and originally sat on the edge of a vast artificial lake (NGR: SP 26750 72500). Although the site had ceased functioning as a pleasure garden by the 16th century, the remains of the Pleasance are still clearly visible as well-preserved earthworks [Fig. 1]. This remarkable preservation is due in part to later land-use but also to the monument's early recognition as a site of national significance, and its subsequent Scheduling in 1928 (SM No: 1007720). 
Despite the high academic profile of the Pleasance, and the publication of considerable documentary evidence, it has never previously been subjected to a programme of detailed earthwork survey and analysis. This lack of accurate archaeological information was the main driver in English Heritage embarking on a programme of detailed analytical earthwork survey at the Pleasance in 2012. The aim of the archaeological work was to provide new insights in interpretation and understanding which would directly inform future management and protection of the monument. The findings of this new research are presented here. This paper will also consider the Pleasance within its wider context as part of the landscape setting of Kenilworth Castle, and how this landscape may have been used and perceived by those interacting with it.

\section{KENILWORTH CASTLE}

HISTORICAL BACKGROUND

The origins of Kenilworth Castle lie in the 1120s, when Geoffrey de Clinton was awarded land at Kenilworth by Henry I and set about establishing a castle, priory and hunting park. De Clinton was a close ally of the king, and the grant appears to have been specifically designed to counter the dominance of the Earl of Warwick in his Midlands powerbase, situated just $7.5 \mathrm{~km}$ from his principal castle at Warwick. The original form of Kenilworth Castle is unknown, but it is likely that it was defined by a series of earthwork defences. There has been considerable debate as to the date of construction for the massive keep which now forms the only survival from the 12th-century castle. There is a strong case for a date in the 1120s, under de Clinton but with the backing (and funding) of the king, although an alternative case has been made for construction in the late 12th century when the castle was in royal hands. ${ }^{\text {iii }}$ The lack of evidence for a motte at Kenilworth may be considered as strengthen the case for the former. The site was extended in the early 13th century by King 
John, when the outer bailey was encircled with a stone curtain wall studded with regular mural towers, and a surrounding moat, fishponds and the Great Mere were created.

In the 14th century the castle passed into the hands of the Dukes of Lancaster and received significant investment, most notably from John of Gaunt, a younger son of Edward III. Gaunt's work comprised a suite of buildings along the west and south sides of the castle’s inner bailey, including a great hall, great chamber and extensive private apartments. The remodelling created a symmetrical range of buildings when viewed from the west, with the great hall flanked by matching towers. Much has been made of Gaunt's international aspirations, and the level of his investment at Kenilworth is widely viewed as reflecting his lofty ambitions. The closest parallels in scale and expenditure are certainly regal, with similarities to Edward III's work at Windsor. The great hall at Kenilworth was the largest in the country apart from that built at Westminster by Richard II. ${ }^{\text {iv }}$ Gaunt's son Henry Bolingbroke became King Henry IV in 1399, but the Lancastrian patrimony remained significant and Kenilworth became an important Midland stronghold for the crown.

In 1413 the castle passed to Henry V as part of his Lancastrian inheritance and by this time was a large and imposing complex. The survival of the 12th-century keep in particular emphasised the long history of the site and may have been seen as symbolic of royal authority. ${ }^{\mathrm{v}}$ It has been suggested that classical, biblical and other ancient associations could be inherent in any castle, as they would have been viewed as primordial structures. ${ }^{\text {vi }}$ Kenilworth had been used as the backdrop for Arthurian pageantry since the late 13th century, with documentary evidence indicating that a series of tournaments was held at the site and attended by Edward I. ${ }^{\text {vii }}$ The ancient connotations of the castle were complemented by Gaunt's work which provided suites of apartments fit for a king and his retinue. The 
combination of these elements made Kenilworth one of Henry V's favoured residences, with frequent stays throughout his reign.

\section{LANDSCAPE SETTING}

By the 13th century the castle was surrounded by extensive pleasure grounds. At the centre of this lay the Great Mere - a vast sinuous lake extending west from the castle for over a kilometre [Fig. 2]. The mere was bounded by hunting grounds which comprised the Old or Great Park, covering an area of circa 308 hectares (740 acres) to the south of the mere, and the Chase, which lay to the north. The Old or Great Park was laid out in the 12th century and comprised a mixture of woodland and more open areas of wood pasture, and was stocked with fallow deer and other game. ${ }^{\text {viii }}$ By the end of the 17th century the entire area had been disparked, the Great Mere drained and the former pleasure grounds turned over to agricultural use. The curving boundary of the extensive medieval hunting parks can still be traced in the sinuous pattern of hedgerows which characterise the landscape today.

To the east of the castle, beyond the area of pleasure grounds, lay Kenilworth Abbey, founded by Geoffrey de Clinton as an Augustinian Priory of the Blessed Virgin Mary in 1122. Relatively little of the monastic complex now survives above ground beyond the 14th century gatehouse and the 'Abbey Barn'. Excavations were undertaken at the site in the 19th and early 20th centuries and uncovered elements of the Abbey church and cloister located on rising ground to the north of the Finham Brook. ${ }^{\mathrm{ix}}$ A string of at least three fishponds and a mill occupied the valley bottom, with the ponds documented from the 16th century. ${ }^{\mathrm{x}}$ The Abbey's precinct boundary is clearly traceable in the landscape today and was originally defined by a stone wall, the upstanding remains of which can still be seen in the north-east angle of the enclosure. 
To the north of the precinct lay the medieval town of Kenilworth, its form and layout shaped by the development of the monastery and castle. Although not strictly part of the pleasure grounds, the town and Abbey were important components of the carefully composed setting of the castle. The main access to the castle from Coventry in the north-east, for example, was through the town, along High Street, and past the impressive monastic complex, the great church of which would have been visible above the precinct wall. The route then descended Castle Hill (formerly New Row) towards the north-eastern angle of the castle's Outer Court. Visitors would then have turned south, passing between the castle and monastic precinct, before finally turning north-west towards the main castle entrance. The primary access into the castle was through a D-shaped outer enclosure named the Brays, probably dating from the 13th century. ${ }^{\mathrm{xi}}$ This outer court was originally defined by a substantial wall, broken by regularly-spaced towers and surrounded by a deep water-filled ditch. The impressive earthworks of the Brays survive largely intact and the masonry footings of the entrance gate are still clearly visible as the visitor approaches the castle from the south.

\section{THE PLEASANCE}

\section{DOCUMENTARY EVIDENCE AND PREVIOUS RESEARCH}

'There was a fox-ridden place overgrown with briars and thorns. He [the king] removes these and cleanses the site so that wild creatures are driven off. Where it had been nasty now becomes peaceful marshland; the coarse ground is sweetened with running water and the site made nice. So the king considers how to overcome the difficulties confronting his own Kingdom. He remembers the foxy tricks of the French both in deed and in writing and is mortified by the recollection. ${ }^{\text {xii }}$

The above quotation comes from the court poet Thomas Elmham, and is thought to represent a contemporary account of the construction of the Plesauns en Mary or the 
‘Pleasance on the Marsh’. Elmham’s Liber metricus on the life of Henry V places the construction of the Pleasance in the spring of 1414, probably reflecting a desire to present the event as a forerunner to Henry’s first successful French campaign, with all the allegorical and symbolic significance that would bring. Colvin argues for the construction of the pleasure garden in the years 1417-8, xiii despite a lack of direct source material. Notwithstanding the discrepancy in dating, construction of the Pleasance can confidently be ascribed to within a very short time scale in the early 15th century.

Harvey’s presentation of the 15th-century documentary evidence for maintenance and construction at Kenilworth Castle gives tantalising clues to the form of the Pleasance and its role in relation to the castle. This includes mention of work to 'les aleyes' (avenues) in 14623, repairs to a number of towers including 'Clarence Tower' and even the repair and caulking of the king's barge. ${ }^{\text {xiv }}$ The records relating to the use of the site under Henry V and his 15thcentury successors, have led Harvey to go so far as to suggest that the Pleasance was used as a residence in preference to the more formal suites at the castle. ${ }^{\mathrm{xv}}$ Henry $\mathrm{V}$, for example, is recorded as meeting his queen there after they had been on separate progresses in $1421 .{ }^{\text {xvi }}$ Documentary sources indicating the Pleasance was used for accommodation regularly throughout the 15th century, ${ }^{\text {xvii }}$ with its close proximity to the Chase suggesting it may have functioned in a similar way to a hunting lodge. References in the 15th century to repairs and alterations at the site indicate its status, as it is referred to as 'the manor of Pleasance' on more than one occasion. ${ }^{\text {xviii }}$

After the abandonment of the site in the early 16th century, on the instructions of Henry VIII, further clues to the form of the site are provided. Leland describes how the 'praty banqueting house of timber that stood thereby in the mere, and bore the name pleasaunce', was taken down and part of it set up in the base court of the castle. ${ }^{\text {xix }}$ Dugdale's 
1656 views of the castle include a depiction of this building, shown to the west of the great hall, although Molyneux has questioned this location on the basis of its inconsistency with late 16th-century surveys of the site. ${ }^{\mathrm{xx}}$

The Pleasance has been the subject of considerable scholarly attention. In the mid20th century this work highlighted the site as an unusually well-documented example of a medieval garden. ${ }^{x x i}$ In more recent times, as debates over designed medieval landscapes have evolved, the Pleasance has frequently been cited as an example of landscape manipulation in the later medieval period. It has been used to illustrate deliberate and careful landscape design, and as an example of a site which may suggest a lack of aesthetic considerations in medieval landscapes. ${ }^{\text {xxii }}$ These discussions have largely rehearsed the evidence first presented by Harvey, Colvin and Thompson, albeit within new theoretical and methodological constructs.

The documentary evidence has been corroborated by surveys of the site, largely derived from the 1926 Ordnance Survey 25 inch map. There was also a small excavation undertaken in 1923 which uncovered the remains of one of the corner towers, the base of a spiral stair and evidence of high-quality architectural features including glazed windows and fine leadwork. ${ }^{\text {xiii }}$ More recently geophysical survey work on the main central platform has verified, amongst other things, the presence of the three corner towers and the base of the former banqueting house. ${ }^{\text {xxiv }}$ This evidence has been used to confirm a basic plan of the site which has been frequently reproduced. ${ }^{\mathrm{xxv}}$

\section{DESCRIPTION AND ANALYSIS OF THE EARTHWORK REMAINS}

The remains of the Pleasance are located within an enclosed pasture field on land sloping gently from north-west to south-east, at approximately $82 \mathrm{~m}$ above OD. The site takes the form of a large double-moated enclosure and is defined by a series of concentric grass- 
covered banks and ditches. The substantial earthworks delineate a central diamond-shaped platform of just over one hectare in area, configured roughly north-south with the corners aligned on the cardinal points [Fig 3]. The concentric moats surrounding the platform still hold water in places and are fed by a series of natural underground springs, with a modern pond now occupying a central position within the outer moat on the north-west side. An overflow channel from the moat can be traced as a shallow ditch running south-west from the southern corner of the inner moat, and would have fed excess water out into the Great Mere.

\section{The middle bank}

The encircling moats are separated by a broad flat-topped bank which is notably more substantial along the monument's south-east side, where it reaches a maximum of $25 \mathrm{~m}$ in width. Along the remaining three sides the middle bank ranges from $8-12 \mathrm{~m}$ wide, with a number of low parallel banks at intervals along its length. The recent survey work identified a number of buildings placed on this broad middle bank, including a small stone-footed structure (b) measuring $3.6 \mathrm{~m}$ by $3.8 \mathrm{~m}$ internally. A slightly larger single-cell structure (f) was recorded on the bank's extreme southern corner, with a slight raised platform measuring $10.5 \mathrm{~m}$ by $5.4 \mathrm{~m}$ to its north-west identified as the possible location of a third structure. Other features identified on the middle bank include two L-shaped scarps or banks (i) located at the north and west corners, which may represent the remains of more ephemeral structures or corner viewing points. A terraced platform cut into the inner side of the middle bank at its western corner suggests a structure spanned the moat at this point, and would have facilitated access between the middle bank and central platform. The causeway spanning the inner and outer moats on the north-west side is not an original feature. This access route crosses the outer moat's slight counter-scarp bank, and cuts the middle bank, indicating it represents a later modification. When this access was created is unclear, but it would appear to be in place by the time of the Ordnance Survey 1st Edition Map of 1888. 


\section{The approach}

A striking and unusual feature of the Pleasance is the sub-rectangular dock or basin (a), the scale and complexity of which indicates it must have formed a main component of the principal approach to the garden. Positioned off-centre along south-eastern side of the Pleasance, the dock is $102 \mathrm{~m}$ long and $26 \mathrm{~m}$ wide and still holds water today. A shallow channel, around $17 \mathrm{~m}$ wide, leads from the dock at its southern end and would have facilitated the passage of boats from the Great Mere. The dimensions of the dock indicate it could have comfortably accommodated a row barge or pleasure boat. Water from the outer moat feeds into the dock at its northern corner, with stone revetment walling visible along the dock's short north-western side suggesting the entire dock may have been stone lined. The dock is flanked by broad banks around $1 \mathrm{~m}$ high which are cut by a later field boundary towards their south-eastern end. There is evidence for a series of structures associated with the dock, including a small rectangular building $8.4 \mathrm{~m}$ long and $4.1 \mathrm{~m}$ wide positioned at the southern end of the north-eastern bank. A symmetrical arrangement of earthworks indicates that the dock was flanked by a regular arrangement of structures, possibly including a pair of towers towards the north-west.

On the south-western side of the dock a sub-rectangular hollow (e) represents the remains of a wharf area or landing place where passengers could disembark. The wharf area is around $26 \mathrm{~m}$ long and $16.7 \mathrm{~m}$ wide and impinges on middle bank and outer moat; whether it was constructed of stone or timber is unclear. The wharf is located almost centrally along the south-eastern side of the pleasure garden and would have facilitated direct access onto the middle bank at its broadest point. The relationship between the dock and wharf, and the range of structures identified at the southern corner of the middle bank, suggests visitors arriving by boat progressed south-west from the wharf and accessed the central platform at the southern corner of the site. 
As the documentary evidence cited above clearly highlights, the Pleasance could also be approached on horseback or by foot. This landward approach from the castle would have followed much the same route as the principal right of way from the castle does today along Purlieu Lane, coming upon the Pleasance from the east. However, there is no clear earthwork evidence for access over the outer moat at this point by way of a bridge or causeway. That said, along the north-eastern side of the enclosure is a sub-rectangular island which was formed by diverting the ditch of the outer moat to create a platform $16.4 \mathrm{~m}$ long and $9.2 \mathrm{~m}$ wide (j). The true function of this is unclear, but it could represent an elaborate point of access onto the middle bank from the landward side. If so, the slight earthwork remains of a possible structure on the platform may represent the footings of a gatehouse or bridge. Alternatively, the moated platform may have been created as a small garden to be viewed from the middle bank, or an island to support wildfowl on the moat.

\section{The central platform}

On the central platform buildings were recorded at its north, east and south corners (c), but no evidence for a building on the western corner was identified (though a bridge may have spanned the inner moat at this point as mentioned above). The three rectangular two-cell corner structures are all very similar in size, measuring approximately $11.1 \mathrm{~m}$ long and $8.2 \mathrm{~m}$ wide, and display evidence for stone footings. Excavations at the eastern building in 1923 confirmed this, and showed it to be a storied tower, as the base of a stone spiral stair survived, with a lead window ventilator and fragments of medieval window glass indicating it was an ornately glazed structure. ${ }^{\text {xxi }}$ The southern building has the earthwork remains of a track leading from it to the north-west. This further strengthens the suggestion that access onto the central platform was won from there, with the building possibly functioning as a small gate tower. Along the south-eastern side of the central area a small terraced platform was identified (d), and represents the position of a single-cell structure which would have 
overlooked the wharf area. It is possible that the whole platform was delimited by an encircling boundary wall linking these structures, although clear evidence for this was not forthcoming.

The main building on the central platform now survives as grass-covered stone footings (g), defining a structure approximately $44.3 \mathrm{~m}$ long and with an external width of 8.4 $\mathrm{m}$. The remains suggest it was a three or possibly a four-cell building. Documentary sources indicate the building, referred to as the 'long house', was taken down and re-erected within the castle precinct in 1524. ${ }^{\text {xxvii }}$ The building in its new location was described in a survey of 1563 as a 'fayerehowse called pleasannce ... having a hale a parlor a buttery a pantry and a ketchyn underneath and above vj very fayer chambers with ynner chambers and other necessary howses thereunto belonging'. xxviii This, in conjunction with the archaeological remains, indicates that it represented a substantial structure comprising a ground-floor hall and all the lordly appurtenances expected from a high-status residence.

To the north-east of the long house slight linear earthworks hint at a regular layout of gardens, and may represent vestiges of walkways defining separate compartments. The garden covered an area of approximately 0.7 ha, with a hexagonal area of compacted ground identified through geophysical survey at its north-western side, part of which is visible as an earthwork (h). This feature has been interpreted as possibly representing the vestiges of a courtyard or formal garden, ${ }^{\text {xxix }}$ and would have been located directly below the first-floor chambers of the main residence. The ornately-glazed towers on the north and east corners of the garden could also have functioned as enclosed viewpoints from where to appreciate the ornamental gardens from above. 
Much has been made of the significance of the Pleasance as a detached garden, in the tradition of those seen at high-status secular and ecclesiastical complexes in the late 13th and 14th centuries. The description of the site as a virandarium in contemporary documents emphasises its role as a pleasure garden. Medieval illustrations typically represent these sites as the 'hortus conclusus', a walled and secluded space in which planting and other features were carefully contrived in elaborate plans. Precedents in England to this type of site include a Herbarium at Peterborough Abbey from the late 13th century, ${ }^{\mathrm{Xxx}}$ particularly significant here because of the double moat surrounding it. Other sites include Clun Castle, Shropshire and Cardiff Castle. ${ }^{\mathrm{xxi}}$ It is clear from the documentary and archaeological evidence that the Pleasance included features typically associated with pleasure gardens, focused on the central platform, but probably also including elements on the middle bank. However, it is clear from the scale of the buildings at the Pleasance, and the carefully designed approach, that its role was perhaps more complex than that ascribed to other gardens of this period.

The royal status of the garden's builder also suggests an international, as well as national context to construction. Parallels have been drawn between the site at Kenilworth and that of the Dukes of Burgundy at Hesdin, not least because the parkland there included a complex known as 'the house on the marsh' xxxii This was part of an extensive pleasure ground extending throughout the parkland around the castle, and appears to have sat at the edge of one of the lakes, some distance from the principal residence. The political aspects to this parallel are notable, as the Duke of Burgundy was a key ally in Henry V's attempts to take the French crown and Henry spent much time negotiating with the duke to ensure his compliance. It is certainly plausible that Henry would seek to flatter the Burgundian court by imitation. There is no evidence that Henry V visited the site, but the parks at Hesdin were renowned in the 15th century and the reference to the pleasance as 'on the marsh' may have held some resonance. 
The Pleasance can also be likened to a hunting lodge or retreat, again a type of site seen in conjunction with larger estates in England since the 13th century. There is considerable precedent for this form of site in a royal context. At Everswell, Woodstock (Oxfordshire), for example, a 'pleasure palace' was built for King Henry II, in the grounds of the main house, reputedly for the king to meet his mistress. ${ }^{\text {xxiii }}$ At the palace at Sheen in the late 14th century Richard II constructed a small island retreat referred to as 'la nayght' for Queen Anne, which included a timber framed building with chambers and a kitchen. ${ }^{\text {xxxiv }}$ At a more local level, there is evidence for a double-moated retreat in one of the parks at Warwick Castle. This site, known as Goodrest, is located on the eastern edge of Wedgnock Park, just $3.5 \mathrm{~km}$ from Kenilworth Castle, and comprises an irregular inner moat (formed partly by a pond) and a more regular, square outer moat. The site is known to have existed in the late 14th century when it was used by the earl of Warwick and his family, and was maintained into the 15th century. ${ }^{\mathrm{xxx}}$ The comparable form of the outer moat at Goodrest and the site at Kenilworth are significant, although given the alterations known to have been undertaken at Goodrest in the 15th century it is more likely that it is an imitator rather than a precursor to the Pleasance. Goodrest is also significantly smaller than the Pleasance and some distance from the main castle. The form and scale of the Pleasance in contrast, meant that while it could at times act as a retreat, it was clearly designed to play a more active role in life at the castle when required. Its location, on the mere, removed but not remote from the castle, is suggestive of the wider symbolic and political role this site could encompass.

\section{MOBILITY IN MEDIEVAL DESIGNED LANDSCAPES}

One of the key themes running through the study of medieval gardens is the fluid links between these sites and the elite residences of whose setting they formed a part. ${ }^{\text {xxxvi }}$ In seeking to further understand the Pleasance we must therefore view it as one element of a 
much larger and carefully contrived landscape of pleasure. By the later medieval period this landscape comprised a series of individual monuments or places all of which were invested with complex meaning and symbolism. Medieval pleasure grounds were carefully staged landscapes and appreciation of them required the active participation of the visitor. This involved physical movement through and around the spaces created between these sites, movement which was carefully managed to ensure maximum appreciation of the scene. Mobility can therefore be viewed as the thread which tied these individual places together, the places themselves forming agents of that movement by attracting people to them and repelling others from them. ${ }^{\text {xxxvii }}$ By attempting to understand the fluid mobilities which linked these sites and places, a more dynamic notion of medieval landscapes can emerge. ${ }^{\text {xxxviii }}$

\section{MOBILITY AND THE APPROACH}

The ways in which people were mobilised could vary depending on factors such as topography, gender and social class - creating a range of possibilities. ${ }^{\text {xxix }}$ At Kenilworth, a carefully manipulated and staged approach to the castle was created by constructing ponds, moats and larger expanses of water. These guided and directed access and ensured maximum appreciation of the scene. The backdrop to this watery setting was a wooded hunting ground, the boundary of which was defined by a substantial ditch and bank surmounted by a pale. This park boundary would have served to inhibit movement and establish exclusivity, with all these devices helping to creating a feeling of separation between the lordly classes and the working peasantry.

The principal approach to the Pleasance was by boat or barge, and written sources documenting repairs to the king's barge in $1462-3^{\mathrm{xl}}$ certainly suggests that access to a boat remained an important requirement for the castle community during the 15th century. A 
landward approach along Purlieu Lane also allowed the site to be reached on horseback or by foot, and required the visitor to cross the northern arm of the mere by way of a road causeway. Although both routes necessitated crossing sheets of water, these various forms of mobility would have provided a very different experience for the visitor. They would also have served to reinforce social distinction through an individual's access to them. Travelling to the Pleasance on the King's barge, for example, would undoubtedly have been reserved for the select few and would have served to both create and strengthen social identities.

Such models of mobility can be likened to a precisely choreographed performance, with an audience to watch and appreciate the meaning of the spectacle. ${ }^{\text {xli }}$ The architectural form of Kenilworth Castle - with its massive first-floor hall flanked by towers and facing out over the Great Mere - ensured there were multiple vantage points from where this act of theatre could be viewed. A detailed survey of Kenilworth from the end of Henry VIII's reign, for example, refers to the large windows of the Strong Tower overlooking the park and Great Mere, from where could be seen 'deer courssyd' and 'fysche takyn'. xlii Windows and wallwalks therefore provided a range of opportunities, with an individual's access to particular areas of the castle creating a hierarchy of viewing. ${ }^{\text {xliii }}$

Conversely, passengers on the boat or barge would have been rewarded with a prospect back towards the castle’s grand western façade, a scene which would have altered as the journey progressed. The Pleasance itself would initially have been hidden from the visitor's gaze, only revealed as the craft rounded the hill on the north side of the mere. As the castle slipped out of view the Pleasance became the main focus, and was carefully constructed and orientated to ensure maximum visual impact. The architectural elements deployed on the garden's south-eastern side would have helped define the space and draw the visitor's eye, both upwards towards the skyline and across the site. This would have served to 
make the Pleasance appear larger and more impressive to approaching guests. The natural topography also played an integral part in this elaborate stage set, the hill used like a theatrical device to surprise and delight visitors as they made their way towards the pleasure garden.

MOBILITY AND THE WIDER PERSPECTIVE

Travelling over water would also have afforded a different outlook on the wider landscape. This vantage point may have allowed passengers a glimpse of deer grazing in the hunting park, fish swimming in the Great Mere or wildfowl skimming its surface. The mere itself would have appeared larger when floating across it in a small craft. Other factors such as the time of year, the time of day and weather conditions would have ensured that the experience was ever changing. Mobility and movement could therefore provide a fresh view on the landscape, bringing visitors closer to aspects of the natural and manmade environment which held deeply symbolic meaning in the medieval period. Fresh water in medieval Christian literature and the arts was associated with life, birth and baptism, sustenance and redemption; it is seen in the bible as a powerful purifying element that can destroy evil and enemies. ${ }^{\text {xliv }}$ Perceived understanding of the symbolic meaning of this watery setting would have varied depending on the observer, with visitors engaging and interacting with their surroundings at different levels depending on their social class or gender. ${ }^{x l v}$ The result of this was that both landscape and traveller were constructive of each other. ${ }^{\text {xlvi }}$

Travelling to the Pleasance on foot or on horseback would have involved climbing the low hill on the north side of the mere. In the medieval period this natural rise would have provided an impressive viewing point back towards the castle, over the glistening surface of the lake, with the high places of Kenilworth Abbey visible behind. The modest elevation would have allowed images reflected in the surface of the water to be seen and appreciated: 
the blue of the sky, the organic forms of the landscape and the bolder lines of the castle itself. The deliberate manipulation of the properties of water has been highlighted as a key feature of many medieval designed landscapes. ${ }^{\text {xlvii }}$ At Kenilworth, the Great Mere would have swept up almost to the foot of the curtain wall, allowing the buildings of the castle to be reflected in the enveloping sheet of water [Fig. 4]. The consequence of this may have been to make the structure seem larger and even more impressive when viewed from a distance - a great red edifice sitting on an impregnable island. It could also have served to reflect the associated symbolisms of water back onto the castle itself, allowing it to be read as a structure capable of destroying evil and enemies. Water also reflects light, with its refractive properties allowing normally dark sides of the landscape to be illuminated.

Mobility can also be bound up with a host of different sensory experiences beyond the visual. ${ }^{x l v i i}$ To take an example, the relatively leisurely pace of a boat or barge moving across a calm sheet of water would have afforded passengers time to appreciate the cooling breeze on their face, hear the sound of the waves lapping against the sides of the craft, and perhaps register the changing aromas of the natural world as it glided past. These experiences both added to and were created by the practice of moving. Contemporary illustrations suggest that music often formed part of the medieval pleasure-boating experience [Fig. 5]. It is therefore probable that music played a role in the performance at Kenilworth, enhancing the spectacle for both passengers and audience alike. Music can stimulate emotions and create a specific mood; through the choice of music a particular atmosphere can be created and a unique experience of mobility formed.

MOBILITY AND THE PLEASANCE

The form and layout of the Pleasance suggests it was deliberately designed to order and guide movement, in much the same way as has been discussed for the spatial planning of 
elite residences. ${ }^{\text {xlix }}$ However, in contrast to domestic structures, medieval gardens were deliberately set apart from the mundane activities of daily life. This may in part explain the secluded location of the Pleasance - positioned on the far edge of the Great Mere and out of view from all but the loftiest parts of the castle. Medieval gardens of the secluded 'hortus conclusus' type had explicit connotations of femininity, a theme frequently demonstrated in contemporary art and literature. The commissioning of the Pleasance by Henry V at a time when he had no immediate prospect of marriage however, suggests that this interpretation for the Pleasance may be, at best, too simplistic. The garden could have had an intimate or family role, but it cannot, at least initially, be seen as a predominantly female space. It may be atypical in this respect, as its size and complexity suggest a more multifarious function, but it could also indicate that 'male' and 'female' areas of the castle or household were perhaps more fluid and less clearly defined.

The feeling of isolation and separation created by travelling to the Pleasance would have been an integral part of the visitor experience, with the enclosed space of the garden revealed to guests in a series of carefully controlled stages. Passengers arriving by boat or barge, for example, were initially funnelled towards the confined space of the dock, which would have been in stark contrast to the open expanse of the mere. The structures of the dock would have served to restrict views and to channel movement, and may have been embellished with heraldic devices and emblems of castle architecture. As such, travelling into and through the dock may be likened to passing through a castle gateway, the action symbolic of social as well as physical progress. ${ }^{l}$ Beyond the dock, the visitor would have progressed on foot from the wharf towards the south corner crossing, the main garden only revealed when the inner moat was crossed and the central platform finally won. 
The design of the garden created linear walkways where visitors could participate in strolling conversations away from the gaze of the household. Contemporary illustrations commonly show pathways in medieval gardens covered by tunnel arbours or flat-topped pergolas which created areas of shade and seclusion. ${ }^{\text {li }}$ The broad banks separating the double moat of the Pleasance formed a private space - a raised walk or garden - which was effectively surrounded by water and existed outside the bounds of the main enclosed garden. Structures placed on the northern and western corners of this area may represent shaded places, created for visitors to sit in quiet contemplation. These areas would have been designed to appeal to all the senses, perhaps incorporating sweet smelling plants and forming vantage points from where the wider setting of the garden could be viewed.

Gardens were contemplative spaces, and are often associated in medieval art and literature with rituals of courtly love and religious symbolism. ${ }^{\text {lii }}$ Gilchrist suggests that the garden was a place where women 'could take their leisure in feminine spaces that were colourful and sweetly scented, a world away from the acrid smells and drab grey of the stable and garrison' liii Whilst gardens undoubtedly had female connotations, aspects of their allure, in courtly romance for example, required male as well as female players. Just as women went hunting and may therefore have interacted with the stables and the garrison, men could also have enjoyed walking in colourful and fragrant spaces. The experience of walking and lingering in such a carefully contrived environment, would have served to stimulate thought and provoke memories. Walking can shape conversations and influence encounters. ${ }^{\text {liv }}$ As spaces for enacting the theatre of courtly ritual, or for more politically motivated meetings, the act of walking around the Pleasance may have helped both male and female participants adjust to the rhythms and views of one another. ${ }^{\text {lv }}$

\section{CONCLUSION}


The recent archaeological survey carried out at the Pleasance by English Heritage has provided significant new insights into the form and function of this royal pleasure garden. It has identified a range of previously unrecorded features, and in doing so, revealed the true scale and complexity of the medieval remains. The work has also allowed a new understanding to be present on how flows of people were managed and controlled around the space. This paper has considered how the medieval pleasure garden may have been perceived by those who experienced it: as a place of retreat or an instrument for carefully structured display; serving as a hunting lodge or as a backdrop to chivalric and romantic scenes. The archaeological investigation also provided an opportunity to examine the wider landscape context of the Pleasance, and this paper has highlighted the connections between the different elements of the medieval landscape setting of Kenilworth Castle. It has also considered how people experienced and perceived this landscape as they moved around and through it, with all the difficulties such an approach brings. Meaning and symbolism are a recurring theme in this paper, as well as the importance of mobility in understanding the social, political and religious imagery ingrained in medieval designed landscapes. This work has also demonstrated the value of accurate field observation, and the reappraisal of approaches to interpreting the evidence, in gaining new insights into monuments and landscapes.

\section{ACKNOWLEDGEMENTS}

The authors are grateful to Henry Lucas the landowner for allowing access to the site, and Ian George, the local Inspector of Ancient Monuments, for his support. Thanks are also due to Pete Herring, Jim Leary and Mark Bowden for reading and commenting on early drafts of the text, and the two anonymous referees for their helpful comments.

\section{BIBLIOGRAPHY}

Adey, P 2010, Mobility, London: Routledge. 
Carey-Hill, E 1927, 'Kenilworth Abbey. A record of the ruins excavated in 1890 and 19223’, Birmingham Archaeol Soc Trans and Proc 52, 184-227.

Colvin, H 1963, The History of the King's Works. Volume 2 The Middle Ages, London: HMSO.

Creighton, 0 2009, Designs upon the Land: Elite Landscapes of the Middle Age, London: Boydell Press.

Dixon, P and Lott, B 1993, 'The courtyard and the tower: context and symbols in the development of late medieval great houses’, J Brit Archaeol Assoc 146, 93-101.

Doig, J 1996, 'Propaganda and truth: Henry V’s royal progress in 1421’, Nottingham Medieval Stud 40, 167-79.

Emery, A 2003, Greater Medieval Houses of England and Wales 1300-1500 Volume 2: East Anglia, central England and Wales, Cambridge: Cambridge University Press.

Everson, P 1998, “'Delightfully surrounded with woods and ponds’: field evidence for medieval gardens in England', in Pattison, P (ed) 1998 There by Design. Field Archaeology in Parks and Gardens. BAR Brit Ser 267, London: Hadrian Books.

Everson, P 2003, 'Medieval gardens and designed landscapes', in Wilson-North, R (ed) 2003 The Lie of the Land: aspects of the archaeology and history of the designed landscape in the South West of England, Exeter: Mint Press, 24-33.

Everson, P and Williamson, T 1998, 'Gardens and Designed Landscapes', in Everson, P and Williamson, T (eds), The Archaeology of Landscape, Manchester: Manchester University Press, 139-65. 
Fairclough, G 1992, 'Meaningful constructions - spatial and functional analysis of medieval buildings', Antiquity 66, 348-66.

Faulkner, PA 1963, 'Castle planning in the fourteenth century’, Archaeol J 127, 130-46.

Flatman, J 2009, Ships and Shipping in Medieval Manuscripts, London: The British Library.

Gilchrist, R 1999, Gender and Archaeology: contesting the past, London: Routledge.

Goodall, J 2011, The English Castle, London: Yale University Press.

Harvey, J 1944, ‘Sidelights on Kenilworth Castle’, Archaeol J 101, 91-107

Harvey, J 1981, Medieval Gardens, London: Batsford.

Ingold, T 2004, 'Culture on the ground. The world perceived through feet', J Material Culture 9(3), 315-40.

Johnson, M 2002, Behind the Castle Gate: from medieval to Renaissance, London: Routledge.

Landsberg, S 1996, The Medieval Garden, London: British Museum Press.

Leary, J 2014, Past Mobilities: Archaeological Approaches to Movement and Mobility, Farnham: Ashgate.

Lee, J and Ingold, T 2006, 'Fieldwork on foot: Perceiving, routing, socializing’, in Coleman, S and Collins, P (eds) 2006 Locating the Field. Space, Place and Context in Anthropology, Oxford: Berg, 67-85.

Leslie, M 1993, ‘An English landscape garden before ‘the English landscape garden’?’, $J$ Garden Hist 13, 3-15. 
Linford, N, Linford, P and Martin, L 2005, Kenilworth Castle, Warwickshire: report on geophysical surveys, June and July 2004 EH: Centre for Archaeology report no 29/2005.

Molyneux, N 2008, ‘Kenilworth Castle in 1563’ English Heritage Hist Review 3, 47-61.

Morris, R 2010, Kenilworth Castle 2nd edition, London: English Heritage.

Murray Phelps, W 1923, 'The Pleasaunce, Kenilworth', Birmingham Archaeol Soc Trans and Proc 49, 61-2.

Richardson, S 2010, ‘A Room With a View? Looking Outwards from Late Medieval Harewood', Archaeol J 167, 14-54.

Thompson, MW 1964, 'Reclamation of waste ground for the Pleasance at Kenilworth Castle’, Medieval Archaeol 8, 222-3.

Tilley, C 1994, A Phenomenology of Landscape: Places, Paths, and Monuments, Oxford: Berg.

Toulmin Smith, L 1964, The Itinerary of John Leland in or about the Years 1535-1543 Volume 2: Parts 4 and 5, London: Centaur Press.

Urry, J 2007, Mobilities, Cambridge: Polity.

VCH 1969, The Victoria County History of the County of Warwick: Vol 8, London: Oxford University Press.

Wheatley, A 2004, The idea of the castle in medieval England, York: York Medieval Press.

Williamson, T and Liddiard, R 2008, 'There by design? Some reflections on medieval elite landscapes’, Archaeol J 165, 520-35. 
Wolffe, B 2001, Henry VI, London: Yale University Press.

\section{LIST OF FIGURE CAPTIONS}

FIG 1

Aerial view of the Pleasance looking east, with Kenilworth Castle beyond.

Photograph by Damien Grady, (C) English Heritage NMR 26228/026.

FIG 2

Reconstruction of the late-medieval landscape surrounding Kenilworth Castle.

Drawn by Elaine Jamieson, (C) English Heritage: Height data licenced to English Heritage for PGA, through Next Perspectives.

FIG 3

The Pleasance: 1:1000 scale earthwork survey (reduced).

Drawn by Sharon Soutar and Elaine Jamieson, (c) English Heritage.

FIG 4

View of the south side of Kenilworth Castle during the floods of early 2014.

Photograph by Elaine Jamieson, (c) English Heritage.

FIG 5

A boating party from a calendar of $c$ 1500, in Gerard Hovenbout Book of Hours (48104).

Reproduced by permission of the British Library Board.

\footnotetext{
'Assessment Team (West), English Heritage. The Engine House, Fire Fly Avenue, Swindon, SN2 2EH, England, UK. Elaine.Jamieson@english-heritage.org.uk

ii Assessment Team (West), English Heritage. The Engine House, Fire Fly Avenue, Swindon, SN2 2EH, England, UK. Rebecca.Lane@english-heritage.org.uk

iii Morris 2010, 37; Goodall 2011, 97; Harvey 1944, 93

iv Emery 2003, 399-402

$\checkmark$ Dixon and Lott 1993, 94

vi Wheatley 2004, 35

vii Morris 2010, 41

viii Harvey 1944, 91-2
} 
ix Carey-Hill 1927

${ }^{x}$ Carey-Hill 1927, 194

xi Morris 2010, 5

xii Thomas Elmham quoted in Thompson 1964, 222

xiii Colvin 1963, 683

xiv Harvey 1944, 101-3

xv Harvey 1981, 97

xvi Doig 1996, 169

xvii see for example Henry VI's itinerary in Wolfe 2001

xviii D.L.29/463/7552 and D.L.29/463/7564 translated in Harvey 1944, 103-4

xix Toulmin Smith 1964, 109

xx Molyneux 2008, 52-3

xxi Harvey 1944; Colvin 1963; Thompson 1964

xxii for example: Leslie 1993, Johnson 2002, Creighton 2009; Williamson and Liddiard 2008

xxiii Murray Phelps 1923

xxiv Linford et al 2005

xxv for example: Colvin 1963, Figure 58; Johnson 2002, Figure 5.1; Creighton 2009, Figure 15

xxvi Murray Phelps 1923, 62

xxvii Molyneux 2008, 52

xxviii Chirk survey quoted in full in Molyneux 2008, 59-61

xxix Linford et al 2005, 12

xxx Harvey 1981, 84

xxxi Everson 1998, 33; Creighton 2009, 66

xxxii Harvey 1981, 106; Creighton 2009, 84

xxxiii Creighton 2009, 141

xxxiv Colvin 1963, 998

xxxv VCH 1969, 469

xxxvi Everson and Williamson 1998

xxxvii Urry 2007

xxxviii Leary 2014

xxxix Tilley 1994

${ }^{x l}$ Harvey 1944, 101-3

xli Leary 2014

xlii Harvey 1944, 93

xliii Richardson 2010

xliv Flatman 2009

xlv Johnson 2002, 48

xlvi Ingold 2004

xlvii for example: Everson 1998, 33; Creighton 2009; 77

xlviii Adey 2010

xlix for example: Faulkner 1963; Fairclough 1992

' Johnson 2002, 72

li Landsberg 1996

lii Everson 2003

liii Gilchirst 1999, 126

liv Adey 2010

Iv Lee and Ingold 2006 